\title{
OCCURRENCE OF GROWTH FACTORS AND THEIR RECEPTORS IN TUBAL PREGNANCY-AFFECTED TISSUE
}

\author{
Anna Kukanova, Māra Pilmane, and Dace Rezeberga \\ Institute of Anatomy and Anthropology, Rīga Stradinš University, Kronvalda bulv. 9, Rīga, LV-1010, LATVIA; \\ E-mail: dr.anna.kukanova@gmail.com.
}

Department of Obstetrics and Gynecology, Rīga Stradiňš University, Miera iela 45, Rīga, LV-1013, LATVIA

Contributed by Māra Pilmane

\begin{abstract}
Considering that growth factors orchestrate cell growth, differentiation and proliferation, the aim of our study was to determine the occurrence of some growth factors and their receptors in tubal pregnancy tissues. The immunohistochemical distribution of TGF beta 1, bFGF, FGFR, NGF, NGFRp75, IGF-1, IGF-1R was determined semiquantitatively. A Mann-Whitney $U$ test for the nonparametric rank analysis was used to test for differences between the factors. Significance was assumed for a $P$ value of $<0.05$. The analysed tissues expressed more FGFR than bFGF ( $U=$ 23; $\mathrm{P}<0.05)$. NGF appeared in various structures of fallopian tube and conceptus but NGFRp75 was particularly absent $(U=1 ; \mathrm{P}<0.05)$. IGF-1 was widely distributed in both mother and embryo tissues, but IGF-1R only in some of the material $(U=22.5 ; \mathrm{P}<0.05)$. It was concluded that TGF beta 1 is absent both in mother and conceptus tissues; fallopian tube tissues express more FGFR than bFGF and suggest the stimulation of compensatory adaptation of the organ and the disturbance of angiogenesis; the presence of NGF in the fallopian tube with absence of NGFRp75 indicates the failure of innervations, angiogenesis and cell interaction; the deficit of IGF-1 and the absence of IGF-1R are suggested to be a result of gestation growth restriction and impaired invasion.
\end{abstract}

Key words: growth factors, implantation, tubal pregnancy, immunohistochemistry.

\section{INTRODUCTION}

Aetiology of ectopic gestation is not clearly understood. Implantation of embryo, further trophoblast invasion and formation of placenta are the main features of pregnancy. Previous research of abnormally implanted embryo has not shown karyotype changes (Goddijn et al., 1996; Coste et al., 2000). It is possible that fertilized oocyte implantation depends on the relation between embryo and fallopian tube cells. Probably, molecular signalling at the time of blastocyst nidation is the key to explaining normal and abnormal implantation (Attar, 2004). Inflammation may be the cause of ectopic blastocyst implantation, or migration of conceptus may be impaired by hormonal or other factors.

Growth factors are important for regulation of a variety of cellular processes and typically act as signalling molecules between cells. The role of growth factors in aetiology of ectopic pregnancy has not been clearly established. The vascular endothelial growth factor (VEGF) controlling angiogenesis has been shown to participate in pathogenesis of ectopic pregnancy (Lam et al., 2004; Daponte et al., 2005). VEGF is elevated in maternal serum in the case of ectopic pregnancy; however, it has shown a low predictive value for these gestations (Daniel et al., 1999; Fasouliotis et al.,
2004). The transforming growth factor beta 1 (TGF beta 1) superfamily is a large family of proteins that encompasses the sub-families TGF, activins, bone morphogenetic proteins (BMPs) and growth differentiation factors (GDFs). Many cells synthesise TGF beta 1 , which is a multifunctional peptide that controls proliferation, differentiation and other function of cells (Yang et al., 2003). It also participates in migration of mesenchymocytes to the site of skeletogenesis (Atchley et al., 1991), in epithelial-mesenchymal interaction and information of cellular condensation dictating the shape of future skeletal elements (Hall and Miyake, 2000). TGF beta 1 orchestrates complex phenomena, such as inflammation, tissue repair, and neoplastic transformation (it controls cellular transformation from G1/G0 to Sstage) during adult life (Roberts and Spon, 1993; Kingsley, 1994; Massaque, 1996). TGF beta 1 is known to participate in cellular growth regulation, differentiation, apoptosis and immunomodulation (Heldin et al., 1997).

Later, TGF beta1 becomes a promoter of tumour genesis, as it stimulates angiogenesis, immunosupression and extracellular matrix proliferation. Basic fibroblast growth factor (bFGF), a member of the fibroblast growth factor (FGF) family, is stored within basement membranes and binds to the heparane sulfate chain of proteoglycane. bFGF can be 
accumulated in the nucleolus, where it stimulates ribosomal protein transcription (Bouche et al., 1987). bFGF appears in maternal circulation during pregnancy, with peak values late in the 2nd trimester. It is associated with a circulating binding protein derived from the extracellular domain of the FGFR1 receptor. The levels of bFGF in maternal serum correlate positively with foetal size, both in the 2 nd trimester and at term (Hill et al., 1998). bFGF is one of the factors involved in mediating the angiogenesis, proteolysis and apoptosis during the implantation (Zygmunt et al., 2003; Liu et al., 2005).

Fibroblast growth factor receptor 1 (FGFR1) also is a widely distributed membrane receptor of developing human tissues including neurons, vascular basement membranes, skin, and bone growth plates. It can be found in membranes of most anchorage dependent cells also around and in their nuclei (Hanneken, 1994; Wang, 1994).

We previously established that TGF beta1 and FGFR1 are common growth factors in actively developing and differentiating human tissue in early embryogenesis (Kukanova and Pilmane, 2007). Nerve growth factor, a protein of the mammalian neurotrophin family, was originally identified as an essential factor that promotes survival, differentiation and myelination of neurons (Yamashita et al., 2005). Signalling by its receptor NGFRp75 during neuronal development has been implicated in diverse neuronal responses, including increased differentiation or survival, inhibition of regeneration, and initiation of apoptotic cell death (Miller and Kaplan, 2005).

Recently it was found that NGF is not only a neurotrophin and proinflammatory factor, but also an activator of endothelial cells and can play a role in mediating angiogenesis (Rahbek et al., 2005; Park et al., 2007). Further research showed that NGF can be a mandatory factor for pregnancy via inhibition of paternal MHC II molecule expression on trophoblast cells (Tometten et al., 2005). The authors concluded that NGF provides a functional link between the nervous, endocrine and immune systems, translating environmental or endocrine signals during pregnancy into an immunological answer.

The biological role of NGFRp75 is to modulate tyrosine-protein kinase receptor activity (Mahadeo et al., 1994; Vesa et al., 2000). However, other functions of NGFRp75 have been established: it regulates neurotrophin retrograde transport (Curtis et al., 1995), influences Schwann cells migration (Anton et al., 1994), and activates some transcriptional factors (Carter et al., 1996). NGF through NGFRp75 both activate apoptosis and prevent programmed cell death (Casaccia et al., 1996; Frade et al., 1996; Rabizadeh et al., 1993).

The study of embryonic nervous tissue has shown that NGFRp75 is widespread on membranes of nerves, muscle fibres and blood vessels, which indicates that NGFRp75 has an important integrative role in first trimester of pregnancy (Kukanova and Pilmane, 2006). Insulin-like growth factor 1
(IGF-1) binds to specific IGF receptors present on many cell types in many tissues (Butler et al., 2002). IGF-1 is one of the most potent natural activators of the cell growth and multiplication and a potent inhibitor of programmed cell death (Yu et al., 2008).

Almost every cell in the human body is affected by IGF-1, especially cells in muscle, cartilage, bone, liver, kidney, nerves, skin, and lungs. In addition to the insulin-like effects, IGF-1 can also regulate cell growth and development, especially in nerve cells, as well as cellular DNA synthesis (Rincon et al., 2005; Ye and D`Ercole, 2006).

Knowledge of the distribution of other growth factors in ectopic pregnancy tissue is limited although many factors and their receptors regulate cellular events in early embryonic period. Considering that growth factors orchestrate cell growth, differentiation and proliferation during embryogenesis, the aim of our study was to determine the occurrence of some growth factors and their receptors in tissues affected by tubal pregnancy.

\section{MATERIALS AND METHODS}

Human oviduct parts were obtained from 12 patients who had underwent salpingoectomy for tubal pregnancy with informed consent. Age, parity, contraception method, pelvic inflammatory and sexually transmitted disease episodes, and partner count of all the patients, were considered (Table 1). The average patient age was 29 years (23-43). Ectopic pregnancy was the first for three patients, second for six, third for two and fifth for one patient. Six (50\%) patients had previously documented pelvic inflammatory disease (PID) episodes, and one had undergone right-sided salpingectomy due to previous ectopic pregnancy. Only one of them had used an intrauterine device (IUD) for contraception. The number of partners and legal abortion count were not significantly different.

The research was conducted with the permission of Ethical Committee of Rīga Stradiņš University (18 December 2007).

The tissue samples were fixed in $2 \%$ formaldehyde and $0.2 \%$ picric acid mixture with $0.1 \mathrm{M}$ phosphate buffer $(\mathrm{pH}$ 7.2). Then samples were rinsed in thyroide buffer containing $10 \%$ sacharose and embedded in paraffin. The tissues were cut into 6-ğm-thick sections and were dewaxed with toluene and rehydrated through a graded ethanol series. The sections were stained with haematoxylin and eosin (H\&E) using standard procedures for slide preparation.

We used the biotin-streptavidin method (Hsu et al., 1981) for determination of transforming growth factor beta 1 (TGF beta 1 mouse monoclonal [TB21] to TGF beta 1 (ab1279), dilution 1 : 1000, Abcam UK); basic fibroblast growth factor (FGF basic rabbit polyclonal to bFGF (ab16828), dilution $1: 200$, Abcam, UK); fibroblast growth factor receptor 1 (FGFR1 rabbit polyclonal to FGFR1 (ab10646), dilution 1 : 100, Abcam UK); nerve growth fac- 
SUMMARY OF PATIENT DATA

\begin{tabular}{|c|c|c|c|c|c|c|c|c|}
\hline $\mathrm{N}$ & Age, years & Pregnancy, n & Abortion, $\mathrm{n}$ & PID, episode $n$ & $\begin{array}{c}\text { Previous tube } \\
\text { surgery }\end{array}$ & STS & Contraception & Partner, $\mathrm{n}$ \\
\hline 1 & 23 & 1 & 0 & 0 & & 0 & none & 5 \\
\hline 2 & 24 & 1 & 0 & 2 & & 0 & none & 1 \\
\hline 3 & 24 & 2 & 1 & 2 & & 0 & none & 3 \\
\hline 4 & 25 & 2 & 1 & 0 & & 0 & none & 4 \\
\hline 5 & 25 & 5 & 3 & 0 & & 0 & none & 1 \\
\hline 6 & 26 & 1 & 0 & 0 & & 0 & none & 3 \\
\hline 7 & 27 & 3 & 2 & 2 & & 0 & none & 3 \\
\hline 8 & 30 & 2 & 1 & 0 & & 0 & none & 1 \\
\hline 9 & 31 & 3 & 2 & 1 & & 0 & none & 1 \\
\hline 10 & 35 & 2 & 1 & 2 & & 0 & none & 5 \\
\hline 11 & 38 & 2 & 1 & 1 & & $\begin{array}{l}\text { Chlamidia; } \\
\text { micoplasmata }\end{array}$ & IUD (2 years) & 1 \\
\hline
\end{tabular}

PID, pelvic inflammatory disease; STS, sexually transmitted disease; IUD, intrauterine device

tor (NGF rabbit polyclonal to NGF (ab6199), dilution 1 : 500, Abcam, UK); nerve growth factor receptor (NGFRp75 mouse polyclonal to p75 (M3507), dilution 1 : 150 DACO, Denmark); insulin-like growth factor 1 (IGF-I goat polyclonal to IGF-1 (MAB291), dilution 1 : 100, RnD systems, Germany); and insulin-like growth factor 1 receptor (IGF-IR mouse monoclonal to IGF-1R (AF-305-NA), dilution 1:100, RnD Systems, Germany).

At least five microscopic fields (X200) were analysed using a microscope (Leica DM RB, Leica Microsystems, Germany).

The distribution of the factors was detected semi quantitatively (0/- occasional positive structures in the visual field, + few positive structures in the visual field, ++ moderate number of positive structures, and +++ numerous positive structures (Pilmane et al., 1999)). The data were analysed by nonparametric rank analysis. The Mann-Whitney $\mathrm{U}$ test was used. Significance was assumed for a $P$ value of $<0.05$.

\section{RESULTS}

Routine haematoxylin and eosin slides showed tubal mucosal oedema and marked branching of tubal mucosal folds. Typical features were proliferation of epitheliocytes, infiltration of lymphocytes and leukocytes as well as capillary stasis. The only embryonic structure found in the cases of tubal pregnancy was chorionic villae binding to fallopian tube structures and to germ membranes (yolk sac as well).

Tubal pregnancy preparations immunohisto-chemically differed in occurrence of recurred growth factors (Table 2). Moderate cells showed FGFR and NGF immunoreactivity. However, numerous positive reactions appeared in epithelia of fallopian tube, nerve fibres and citolemmae of muscle cells (Figs. 1 and 2).

IGF-1 was widely distributed in fallopian tube epithelium (Fig. 3), while IGF-1R focally stained apical surfaces of tubal epitheliocytes.

Cytotrophoblast and sincytiotrophoblast contained moderate numbers of FGFR and IGF-1 positive structures. FGFR

Table 2

DISTRIBUTION OF GROWTH FACTORS IN CASES OF TUBAL PREGNANCY

\begin{tabular}{|c|c|c|c|c|c|c|c|}
\hline Structure/ Factor & FGFR & bFGF & NGFRp75 & NGF & IGF1R & IGF-1 & TGF beta 1 \\
\hline Epithelium & +++ & + & $0 /-$ & ++ & + & +++ & $0 /-$ \\
\hline Myocytes & +++ & + & $0 /-$ & ++ & $0 /-$ & $0 /-$ & $0 /-$ \\
\hline Nerve fibres & ++ & + & + & ++ & $0 /-$ & $0 /-$ & $0 /-$ \\
\hline Mesothelium & ++ & + & $0 /-$ & + & ++ & ++ & $0 /-$ \\
\hline Extraembryonic mesenchyma & +++ & $0 / 1$ & $0 /-$ & + & $0 /-$ & + & $0 /-$ \\
\hline Cytotrophoblast & ++ & $0 / 1$ & $0 /-$ & $0 /-$ & $0 /-$ & ++ & $0 /-$ \\
\hline Sincytiotrophoblasts & ++ & $0 / 1$ & $0 /-$ & +++ & $0 /-$ & ++ & $0 /-$ \\
\hline Peripheral trophoblast & + & + & $0 /-$ & + & $0 /-$ & + & $0 /-$ \\
\hline Macrophages & $0 /-$ & + & $0 /-$ & $0 /-$ & $0 /-$ & + & $0 /-$ \\
\hline Neutrophils & $0 /-$ & + & $0 /-$ & $0 /-$ & $0 /-$ & + & $0 /-$ \\
\hline
\end{tabular}




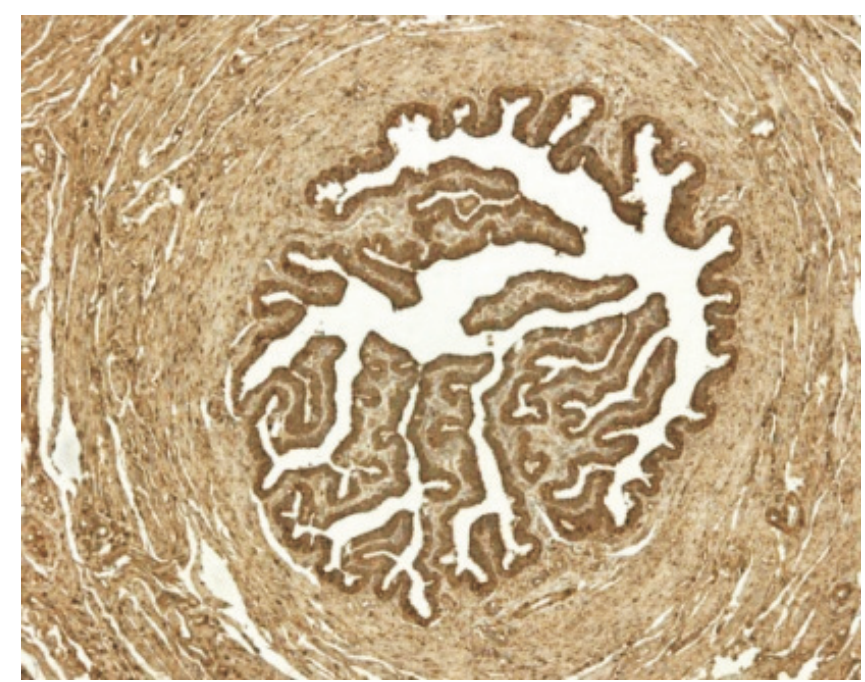

Fig. 1. Abundant FGFR-containing structures in fallopian tube tissue. IMH FGFR, 100x.

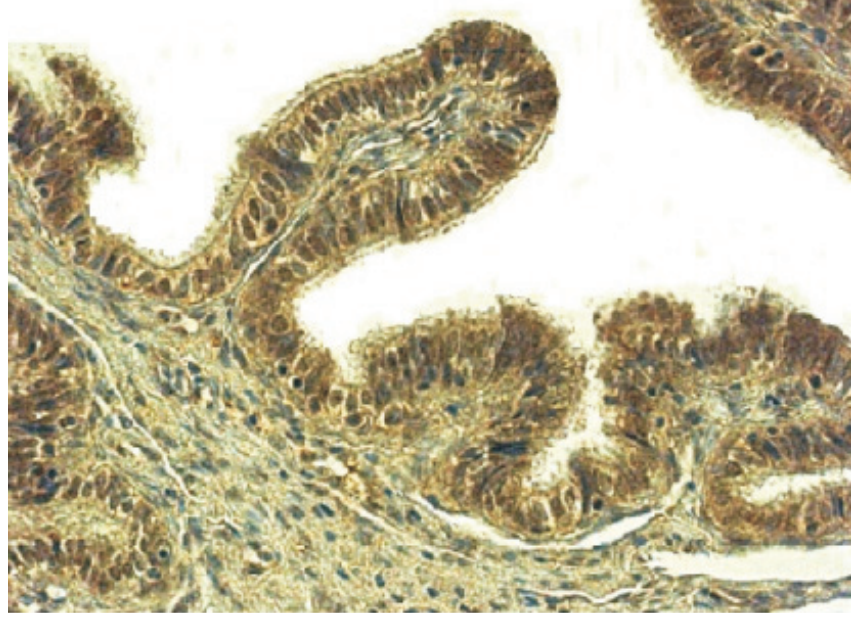

Fig. 2. Moderate positive response for NGF in fallopian tube epithelium. IMH NGF, 400x.

stained all extraembryonic mesenchymal cells, while IGF-1 stained only some of them. Extraembryonic mesenchyma and sincytiotrophoblast showed NGF immunoreactivity (Fig. 5).

Peripheral trophoblast focally contained FGFR, bFGF, NGF and IGF-1 positive cells. IGF-1 and bFGF stained some connective tissue cells, macrophages and neutrophils (Fig. $6)$.

A NGFRp75 focally positive reaction was observed only in nerve fibres (Fig. 7). IGR-1R stained also mesothelium and connective tissue cells (Fig. 8), but was absent in chorionic structures (Fig. 9). The TGF beta 1 negative reaction was typical for all the tissues in all cases of tubal pregnancy we examined (Fig. 10).

The analysed tissues expressed more FGFR than bFGF ( $\mathrm{U}=$ 23; $P<0.05)$. NGF appeared in various structures of the fallopian tube and conceptus, while NGFRp75 was particu-

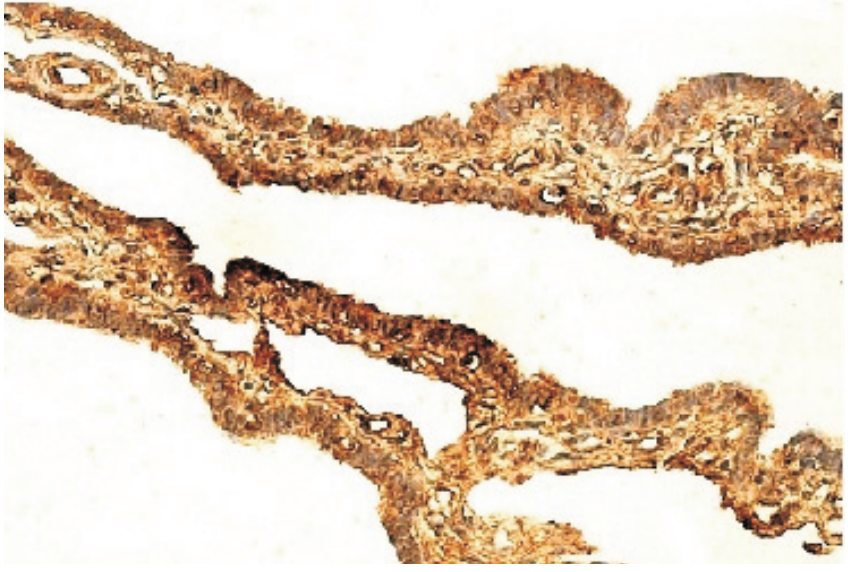

Fig. 3. Numerous IGF-1 positive cells in fallopian tube. IMH IGF-1, 400x.

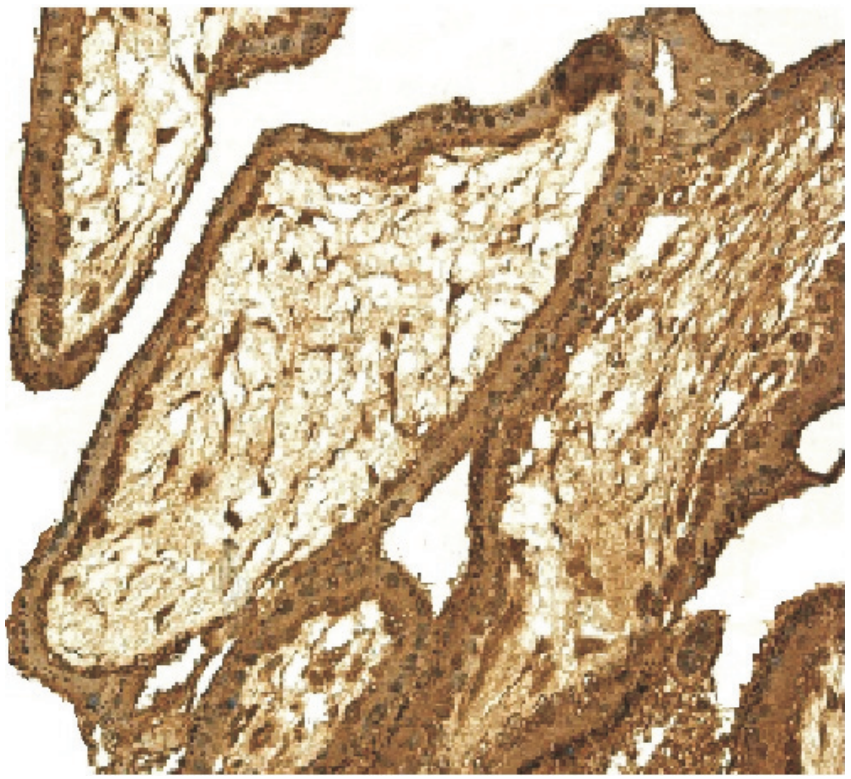

Fig. 4. Chorionic villae demonstrate moderate positive response for FGFR. IMH FGFR, 250x.

larly absent $(\mathrm{U}=1 ; P<0.05)$. IGF-1 was widely distributed in both mother and embryo tissues, while IGF-1R stained only some of them $(\mathrm{U}=22.5 ; P<0.05)$.

\section{DISCUSSION}

TGF beta 1 is essential in many reproductive processes (Jones et al., 2006), respectively, in normal endometrial decidualisation processes (Stoikos et al., 2008). Earlier studies have established the role of the TGF family in trophoblast invasion and have shown absence of TGF beta 1 in villous trophoblasts (Lyall et al., 2001; Simpson et al., 2002). The typical negative TGF beta 1 reaction in all layers of the fallopian tube and chorionic tissue (villous trophoblast as well) observed in our research is an argument for the absence of conceptus-endometrial interaction and indicates the impossibility for gestation to be continued.

The widespread distribution of FGFR1 in a multiple mature organ system suggests an important functional role in nor- 


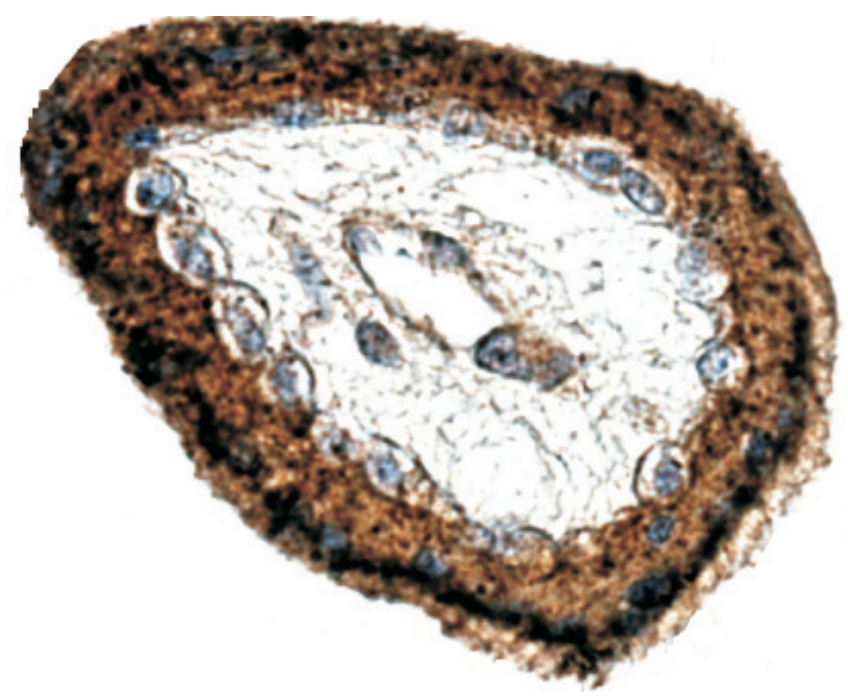

Fig. 5. Sincytiotrophoblast shows a positive reaction for NGF. IMH NGF, $400 \times$.

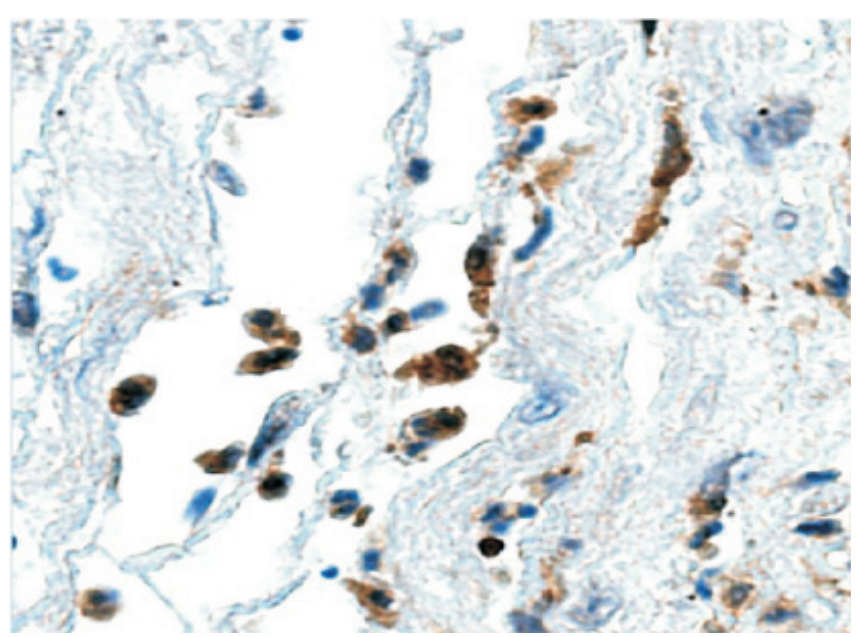

Fig. 6. Some connective tissue cells positive for bFGF. IMH bFGF, 400x

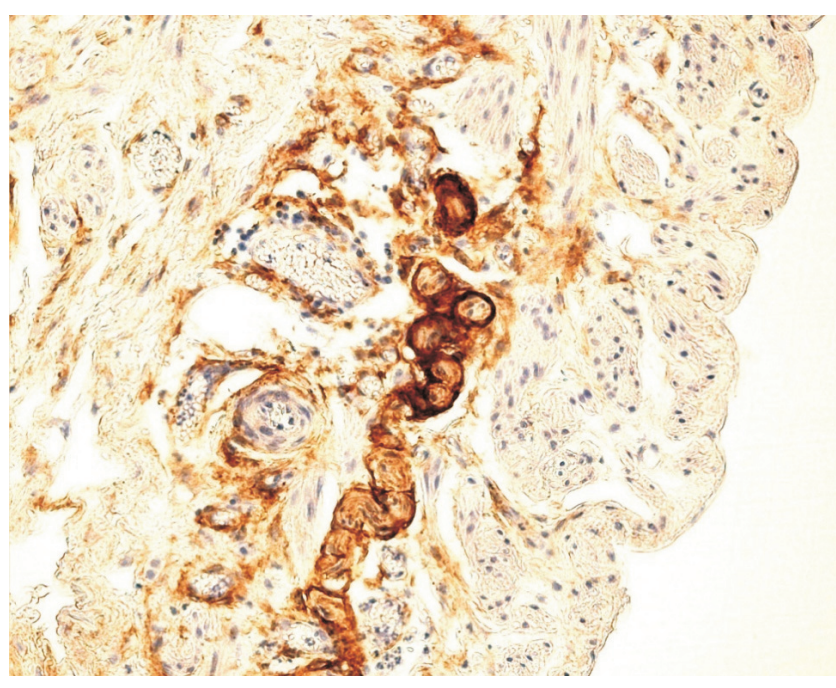

Fig. 7. Nerve fibres stained for NGFRp75. IMH NGFRp75, 250×.

mal human adult tissue (Hughes, 1997). Our previous studies showed that FGFR1 participates in regulation of human embryonic tissue formation (Kukanova and Pilmane, 2007).

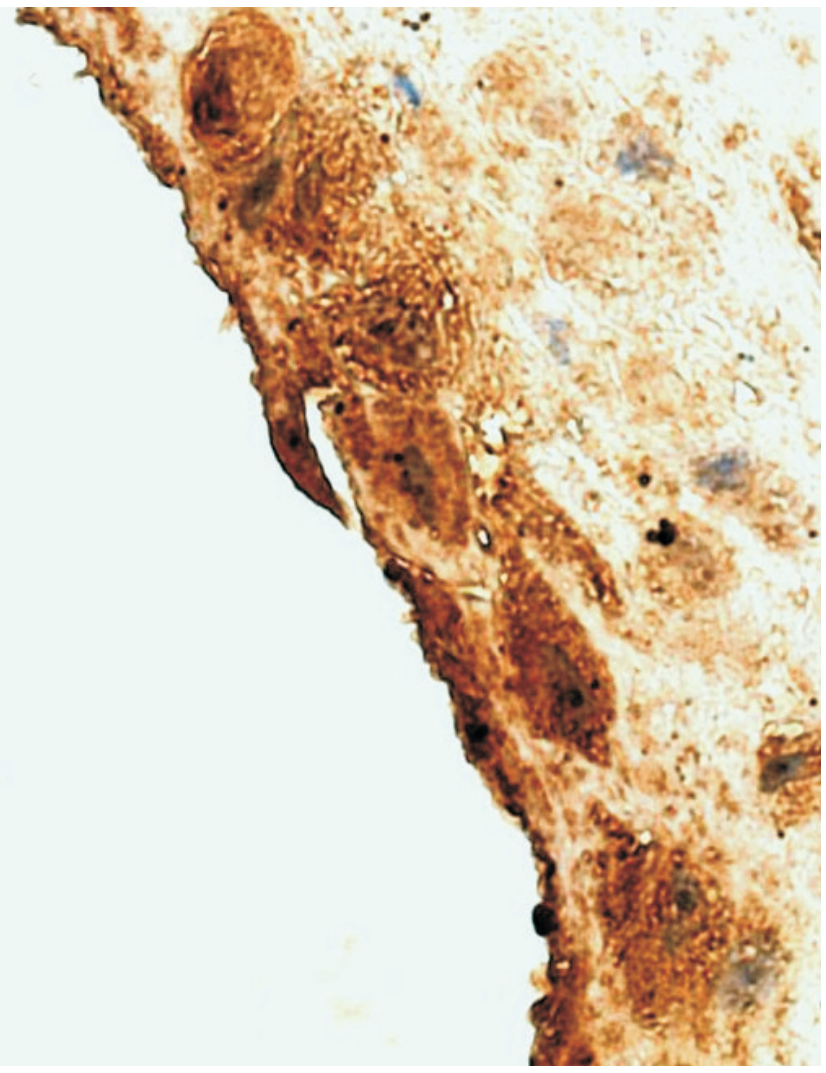

Fig. 8. IGF-1R stained only epithelium and some connective tissue cells IMH IGF-1R, 400x.

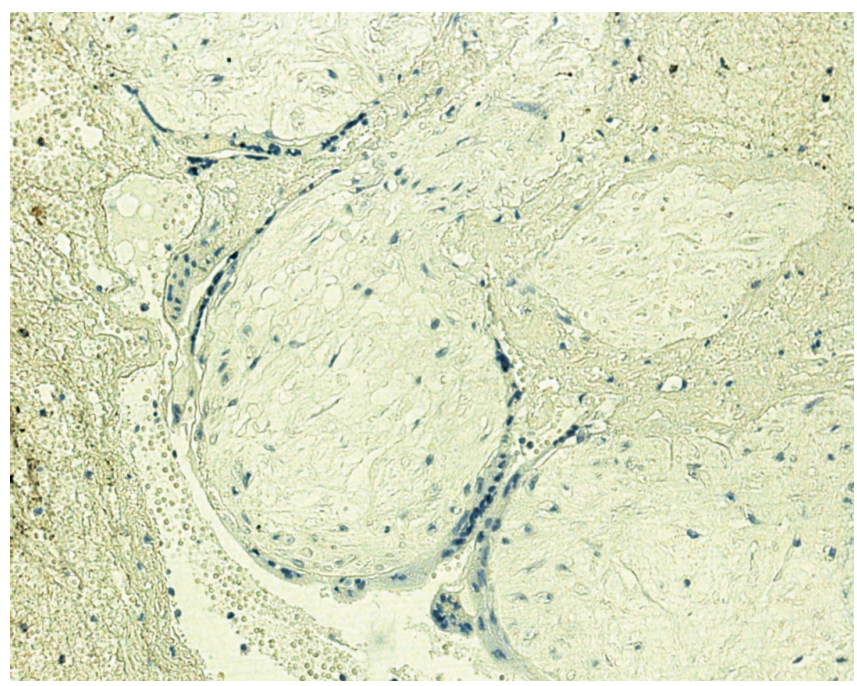

Fig. 9. IGF-1R negative reaction in chorionic villae. IMH IGF-1R, 250x.

We demonstrated that tubal and conceptus tissue contained more FGFR1 than bFGF, and speculate that the excess of receptor is due to compensatory adaptation of the organ to pathologic process. Low occurrence of bFGF possibly indicates abnormal angiogenesis and future cell growth restriction.

Widely distributed NGF immunoreactivity was observed in tubal and trophoblast tissues, with relative absence of NGFRp75. We found NGFRp75 only in nerve fibres of the fallopian tube. These findings suggest a break of links between endocrine, nervous and immune systems in cases of 


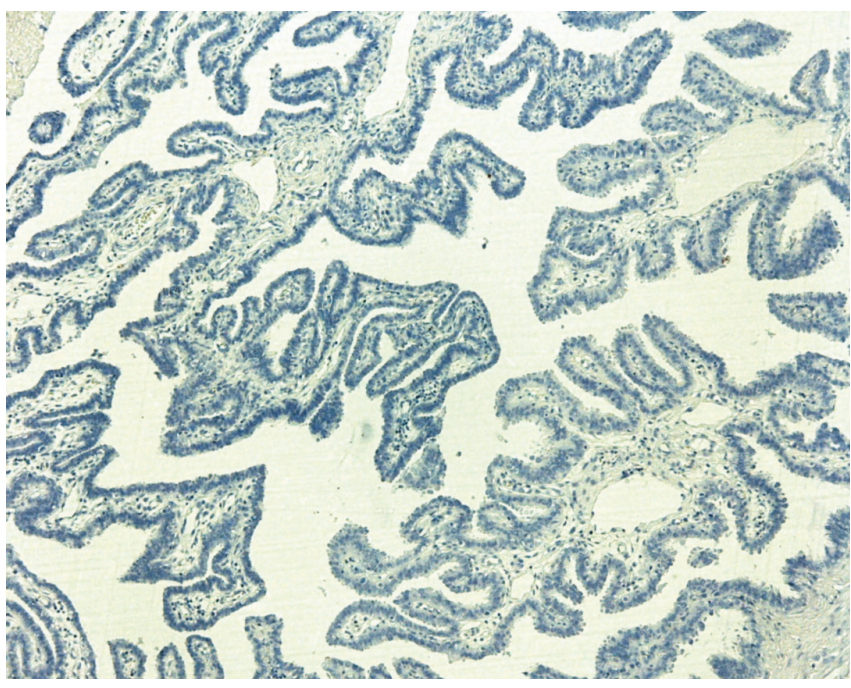

Fig. 10. TGF beta 1 negative reaction in tubal epithelium. IMH TGF beta $1,100 \times$.

tubal implantation with failure of innervation and angiogenesis. Thus, the important process of molecular interaction between mother and conceptus tissue, essential for further development of gestation, is absent due to lack of NGFRp75.

IGF-1 and its receptor (IGF-1R) are essential for embryo growth and survival. Hepatocytes and almost all human tissue synthesise IGF-1 precursor, which requires further enzyme activation. IGF-1R also requires activation to enable function via mature $\alpha$ and $\beta$ chains (Khatib, 2001). IGF-1 ligand binding to its receptor IGF-1R increases proliferation signals and cell survival. Overexpression of IGF-1R in cancer cells results in increased invasion and vice versa (Zhang, 2004). In a mother, circulating levels of IGF-I are increased during pregnancy and are correlated with foetal birth weight. Maternal IGF-I stimulates foetal growth by activating placental transport of nutrients to foetus (Iwashita, 1994). In cases of foetus growth retardation, a compensatory increase of IGF-1 has been observed (Holmes et al., 1999; Ozkan et al., 2008). Decidual placental cells of pre-eclamptic women also demonstrated increased immunoreactivity (Ozkan 2008). In fallopian tube epithelium, trophoblast and connective tissue cells, we demonstrated positive reaction for IGF-1, but all analysed tissues were negative for IGF-1R. This finding may indicate the possible restriction of cell growth and restriction of trophoblast invasion in tissues affected by ectopic pregnancy.

Summarising our results, it is clear that formation of future placenta and development of ectopic pregnancy are impossible because of impaired molecular interaction between mother and embryo. Therefore, important angiogenesis, invasion of trophoblast and cell growth are restricted, and embryo survival is doubtful. However, we cannot still be sure if the abnormal implantation is the reason of these development restrictions, or if developmental restrictions themselves represent compensatory changes in mother tissue, which prevent this abnormal implantation. Future research is necessary to answer these questions.

In conclusion, TGF beta 1 is absent both in mother and conceptus tissues. Fallopian tube tissues express more FGFR than bFGF and indicate the stimulation of compensatory adaptation of the organ and disturbance of angiogenesis. The presence of NGF in structures of the fallopian tube, with absence of NGFRp75, indicates the failure of innervations, angiogenesis and cell interaction. The deficit of IGF-1 and the absence of IGF-1R are suggested to be a result of gestation growth restriction and impaired trophoblast invasion.

\section{ACKNOWLEGEMENTS}

The authors are acknowledged to Latvian Council of Science project No. 09.1405, "Morphopathogenetical research on invalid for implantation and abnormally implanted human embryos to reveal prophylaxis of female infertility".

\section{REFERENCES}

Anton, E.S., Weskamp, G., Reichardt, L.F., Matthew, W.D. (1994). Nerve growth factor and its low affinity receptor promote Schwann cell migration. Proc. Natl. Acad. Sci., 91(7), 2795-2799.

Atchley, W.R., Hall, B.K. (1991). A model for development and evolution of complex morphological structures. Biol. Rev. Camb. Philos. Soc., 66(2), 101-157.

Attar, E. (2004). Endocrinology of ectopic pregnancy. Obstet. Gynecol. Clin. North. Amer., 31(4), 779-794.

Bouche, G., Gas, N., Prats, H., Baldin, V., Tauber, J.P., Teissie, J., Amalric, F. (1987). Basic fibroblast growth factor enters the nucleolus and stimulates the transcription of ribosomal genes in ABAE cells undergoing G0-G1 transition. Proc. Natl. Acad. Sci., 84(19), 6770-6774.

Butler, A.A., Yakar, S., LeRoith, D. (2002). Insulin-like growth factor-I: Compartmentalization within the somatotropic axis? News. Physiol. Sci., 17, 82-85.

Carter, B.D., Kaltschmidt, C., Kaltschmidt, B., Offenhauser, N., Bohm Matthaei, R., Baeuerle, P.A., Barde, Y.A. (1996). Selective activation of NF kappa B by nerve growth factor through the neurotrophin receptor $\mathrm{p} 75$. Science, 272(5261), 542-545.

Casaccia, B.P., Carter, B.D., Dobrowsky, R.T., Chao, M.V. (1996). Death of oligodendrocytes mediated by the interaction of nerve growth factor with its receptor p75. Nature, 383 (6602), 716-719.

Coste, J., Fernandez, H., Joye, N. (2000). Role of chromosome abnormalities in ectopic pregnancy. Fertil. Steril., 74(6), 1259-1260.

Curtis, R., Adryan, K.M., Stark, J.L., Park, J.S., Compton, D.L., Weskamp, G., Huber, L.J., Chao, M.V., Jaenisch, R., Lee, K.F. (1995). Differential role of the low affinity neurotrophin receptor (p75) in retrograde axonal transport of the neurotrophins. Neuron, 14(6), 1201-1211.

Daniel, Y., Geva, E., Lerner-Geva, L. (1999). Levels of vascular endothelial growth factor are elevated in patients with ectopic pregnancy: Is this a novel marker? Fertil. Steril., 72(6), 1013-1017.

Daponte, A., Pournaras, S., Zintzaras, E., Kallitsaris, A, Lialios, G., Maniatis, A.N., Messinis, I.E. (2005). The value of a single combined measurement of VEGF, glycodelin, progesterone, PAPP-A, HPL and LIF for differentiating between ectopic and abnormal intrauterine pregnancy. Hum. Reprod., 20(11), 3163-3166. 
Fasouliotis, S.J., Spandorfer, S.D., Witkin, S.S., Liu, H.C., Roberts, J.E., Rosenwaks, Z. (2004). Maternal serum vascular endothelial growth factor levels in early ectopic and intrauterine pregnancies after in vitro fertilization treatment. Fertil. Steril., 82(2), 309-313.

Frade, J.M., Rodriguez Tebar, A., Barde, Y.A. (1996). Induction of cell death by endogenous nerve growth factor through its p75 receptor. Nature, 383 (6596), 166-168.

Goddijn, M., van der Veen, F., Schuring-Blom, G.H., Ankum, W.M., Leschot, N.J. (1996). Cytogenetic characteristics of ectopic pregnancy. Hum. Reprod., 11(12), 2769-2771.

Hall, B.K., Miyake, T. (2000). All for one and one for all: Condensation and the initiation of skeletal development. Bioassays, 22(2), 138-147.

Hanneken, A. (1994). Identification of soluble forms of the fibroblast growth factor receptor in blood. Proc. Natl. Acad. Sci., 91, 9170-9174.

Heldin, C.H., Miyazono, K., Dijke, P. (1997). TGF-b signalling from cell membrane to nucleus through SMAD proteins. Nature, 390, 465-471.

Hill, D.J., Petrik, J., Arany, E. (1998). Growth factors and the regulation of fetal growth. Diabetes Care, Aug., 21, 60-69.

Holmes, R., Porter, H., Newcomb, P., Holly, J.M., Soothill, P. (1999). An immunohistochemical study of type I insulin-like growth factor receptors in the placentae of pregnancies with appropriately grown or growth restricted fetuses. Placenta, 20(4), 325-330.

Hsu, S.M., Raine, L., Fanger, H. (1981). Use of avidin-biotin-peroxidase complex $(\mathrm{ABC})$ in immunoperoxidase techniques: A comparison between $\mathrm{ABC}$ and unlabeled antibody (PAP) procedures. The Histochemical Society, 29(4), 577-580.

Hughes, S.E. (1997). Differential expression of the fibroblast growth factor receptor (FGFR) multigene family in normal human adult tissues. $J$. Histochem. Cytochem., 45, 1005-1020.

Iwashita, M. (1994). Physiological significance of IGF-I and its binding proteins on fetal growth and maturation. Nippon Sanka Fujinaka Gakkai Zasshi, 46(8), 660-672.

Jones, R.L. Stoikos, C., Findlay, J.K., Salamonsen, L.A. (2006). TGF-beta superfamily expression and actions in the endometrium and placenta. Reproduction, 132, 217-232.

Khatib, A.M. (2001). Inhibition of proprotein convertases is associated with loss of growth and tumorigenicity of HT-29 human colon carcinoma cells: Importance of insulin-like growth factor-1 (IGF-1) receptor processing in IGF-1-mediated functions. J. Biol. Chem., 276(33), 30686-30693.

Kingsley, D.M. (1994). The TGF-beta super family: New members, new receptors, and new genetic tests of function in different organisms. Genes Dev., 8(2), 133-146.

Kukanova, A., Pilmane, M. (2006). Distribution of neuropeptides in human embryonic central nervous system. In: RSU Collection of Scientific Papers (pp. 302-304). Rīga: Rīga Stradiņš University.

Kukanova, A., Pilmane, M. (2007). Distribution of some growth factors and appearance of some genes in different tissues of human embryo. In: $R S U$ Collection of Scientific Papers (pp. 21-24). Rīga: Rīga Stradinš̌ University.

Lam, P.M., Briton-Jones, C., Cheung, C.K., Leung, S.W., Cheung, L.P., Haines, C. (2004). Increased messenger RNA expression of vascular endothelial growth factor and its receptors in the implantation site of the human oviduct with ectopic gestation. Fertil. Steril., 82(3), 686-690.

Liu, Y.X., Gao, F., Wei, P., Chen, X.L., Gao, H.J., Zou, R.J., Siao, L.J., Xu, F.H., Feng, Q., Liu K., Hu Z.Y. (2005). Involvement of molecules related to angiogenesis, proteolysis and apoptosis in implantation in rhesus monkey and mouse. Contraception, 71(4) 249-262.

Lyall, F., Simpson H., Bulmer J.N., Barber A., Robson S.C. (2001). Transforming growth factor-beta expression in human placenta and placental bed in third trimester normal pregnancy, preeclampsia, and fetal growth restriction. Amer. J. Pathol., 159(5), 1827-1838.
Mahadeo, D., Kaplan, L., Chao, M.V., Hempstead, B.L. (1994). High affinity nerve growth factor binding displays a faster rate of association than p140trk binding. Implications for multi subunit polypeptide receptors. $J$. Biol. Chem., 269(9), 6884-6891.

Massaque, J. (1996). TGF beta signaling: Receptors, transducers, and Mad proteins. Cell, $\mathbf{8 5}(7), 947-950$.

Miller, F.D., Kaplan, D.R. (2001). Neurotrophin signaling pathways regulating neuronal apoptosis. Cell Mol. Life Sci., 58(8), 1045-1053.

Ozkan, S., Vural, B., Dalçik, C., Taş, A., Dalçik, H. (2008). Placental expression of insulin-like growth factor-I, fibroblast growth factor-basic and neural cell adhesion molecule in pregnancies with small for gestational age fetuses. J. Perinatol., 28 (7), 468-474.

Ozkan, S., Vural, B., Filiz, S., Coştur, P., Dalçik, H. (2008). Placental expression of insulin-like growth factor-I, fibroblast growth factor-basic, and neural cell adhesion molecule in preeclampsia. J. Matern. Fetal. Neonatal. Med., 21(11), 831-838.

Park, M.J., Kwak, H.J., Lee, H.C., Yoo, D.H., Park, I.C., Kim, M.S., Lee, S.H., Rhee, C.H., Hong, S.I. (2007). Nerve growth factor induces endothelial cell invasion and cord formation by promoting matrix metalloproteinase-2 expression through the phosphatidylinositol 3-kinase/Akt signaling pathway and AP-2 transcription factor. Biol. Chem., 282(42), 30485-30496.

Pilmane, M., Engelis, A., Mozgis, Dz. (1999). Neuropeptides in colon of children with Hirschprung disease. Int. J. Surg. Childhood, 7(4), 223-227.

Rabizadeh, S., Oh, J., Zhong, L.T., Yang, J., Bitler, C.M., Butcher, L.L., Bredesen, D.E. (1993). Induction of apoptosis by the low affinity NGF receptor. Science, 261(5119), 345-348.

Rahbek, U.L., Dissing, S., Thomassen, C., Hansen, A.J., Tritsaris, K. (2005) Nerve growth factor activates aorta endothelial cells causing PI3K/Aktand ERK-dependent migration. Pflugers Arch., 450(5), 355-361.

Rincon, M., Muzumdar, R., Atzmon, G., Barzilai, N. (2005). The paradox of the insulin/IGF-1 signaling pathway in longevity. Mech. Ageing Dev., 125(6), 397-403.

Roberts, A.B., Spon, M.B. (1993). Physiological actions and clinical application of transforming factor beta (TGF-beta). Growth Factors, 8(1), 1-9.

Simpson, H., Robson, S.C., Bulmer, J.N., Barber, A., Lyall, F. (2002). Transforming growth factor beta expression in human placenta and placental bed during early pregnancy. Placenta, 23(1), 44-58.

Stoikos, C.J., Harrison, C.A., Salamonsen, L.A., Dimitriadis, E. (2008). A distinct cohort of the TGF beta superfamily members expressed in human endometrium regulate decidualization. Hum. Reprod., 23(6), 1447-1456.

Tometten, M., Blois, S., Arck, P. (2005). Nerve growth factor in reproductive biology: Link between the immune, endocrine and nervous system? Chem. Immunol. Allergy, 89, 135-148.

Vesa, J., Kruttgen, A., Cosgaya, J.M., Shooter, E.M. (2000). Palmitoylation of the p75 neurotrophin receptor has no effect on its interaction with TrkA or on TrkA mediated down regulation of cell adhesion molecules. $J$. Neurosci. Res., 62, 225-233.

Wang, J.K. (1994). Fibroblast growth factor receptor have different signaling and mitogenic potentials. Mol. Cell. Biol., 14, 181-188.

Yamashita, T., Fujitani, M., Hata, K., Mimura, F., Yamagishi, S. (2005). Diverse functions of the p75 neurotrophin receptor. Anat. Sci. Int., 80(1), $37-41$.

Yang, V.C., Piek, E., Zavadil, J. (2003). Hierarchical model of gene regulation of transforming factor beta. Cell Biol., 100(18), 10269-10274.

Ye, P., D'Ercole, A.J. (2006). Insulin-like growth factor actions during development of neural stem cells and progenitors in the central nervous system. Neurosci. Res., 83(1), 1-6. 
Yu, X.Y., Song, Y.H., Geng, Y.J., Lin, Q.X., Shan, Z.X., Lin, S.G., Li, Y. (2008). Glucose induces apoptosis of cardiomyocytes via microRNA-1 and IGF-1. Biochem. Biophys. Res. Commun., 376(3), 548-552.

Zhang, D. (2004). Dual regulation of MMP-2 expression by the type 1 insulin-like growth factor receptor: The phosphatidylinositol 3- kinase/Akt and
Raf/ERK pathways transmit opposing signals. J. Biol. Chem., 279 (19), 19683-19690.

Zygmunt, M., Herr, F., Münstedt, K., Lang, U., Liang, O.D. (2003). Angiogenesis and vasculogenesis in pregnancy. Eur. J. Obstet. Gynecol. Reprod. Biol., 22(110) 10-18.

Received 11 November 2009

\section{AUGŠANAS FAKTORU UN TO RECEPTORU SADALĪJUMS OLVADA GRŪTNIECĪBAS AUDOS}

Augšanas faktori nosaka šūnas augšanu, diferenciāciju un proliferāciju. Mūsu pētījuma mērḳis bija noteikt dažādu augšanas faktoru sadalījumu olvada grūtniecības audos. TGF beta 1, bFGF, FGFR, NGF, NGFRp75, IGF-1, IGF-1R noteikšanai izmantojām imūnhistokīmisko metodi. Faktoru sadalījumu noteicām puskvantitatīvi, datu statististiskai apstrādei izmantojām neparametrisko Mann-Whitney $U$ testu. Analizētie audi ekspresēja FGFR vairāk nekā bFGF ( $\mathrm{U}=23 ; P<0.05)$. NGF novērojams olvada un conceptus audos, bet NGFRp75 trūkst ( $\mathrm{U}=1 ; P<0.05$ ). Gan mātes, gan embrija audi bagātīgi saturēja IGF-1, bet IGF-1R ir tikai dažās struktūrās $(\mathrm{U}=22.5 ; P<0.05)$. Secināts, ka TGF beta 1 trūkst gan mātes, gan conceptus audos; olvadi ekspresē FGFR vairāk nekā bFGF - tas norāda uz orgāna kompensatoro adaptāciju un angioǵenēzes traucējumiem; NGF olvadā audos NGFRp75 trūkuma gadījumā raksturo inervācijas, angioǵenēzes un šūnu mijiedarbības traucējumus; IGF-1 deficīts un IGF-1R trūkums varētu atspoguḷot gestācijas augšanas aizturi un traucētu trofoblasta invāziju. 